\title{
The importance of runny nose tests in Alzheimer's disease
}

\author{
Alzheimer hastalığ 1 erken tanısında burun akıntısı testlerinin önemi
}

\author{
Kayhan Özkan ${ }^{1}$, Oytun Erbaş²] \\ ${ }^{1}$ Department of Physiology, Duzce University, Institute of Health Sciences, Düzce, Turkey \\ ${ }^{2}$ Department of Physiology, Istanbul Bilim University, Faculty of Medicine, Istanbul, Turkey
}

\begin{abstract}
Alzheimer's disease (AD) is a clinical syndrome characterized by a progressive decrease in activities allowing the ability to carry out basic activities of daily life such as memory, speech, visual functionality, personality, and behavior. There are about 50 million people living with AD worldwide and treatment options are limited. The success of the struggle against disease depends on early diagnosis. Recently, runny nose tests, used in the early diagnosis of $A D$, have an important place in the early diagnosis of the disease.
\end{abstract}

Keywords: Alzheimer's disease, memory, personality, runny nose tests.

\section{ÖZ}

Alzheimer hastalığı (AH) hafıza, konuşma, görsel işlevsellik, kişilik ve davranış gibi günlük hayatın temel aktivitelerini gerçekleştirme kabiliyetinin progresif olarak azalması ile karakterize klinik bir sendromdur. Yeryüzünde AH'li yaklaşık 50 milyon insan yaşamaktadır ve tedavi seçenekleri sınırlıdır. Hastalıkla mücadelenin başarısı erken tanıya bağlıdır. Son yıllarda AH erken tanısında kullanılan yöntemlerden burun akıntı testleri hastalığın erken tanısında önemli bir yer tutmaktadır.

Anahtar sözcükler: Alzheimer hastalığı, hafıza, kişilik, burun akıntı testleri.

A majority of elderly adults show symptoms of a condition known as geriatric rhinitis, or inflammation or irritation of the intranasal mucous membrane. A large extent of viruses, bacteria, irritant substances, or allergens which cause this inflammation lead to irritation which results in nasal discharge or postnasal drip. As age advances, the nasal membrane atrophies and skin loses elastic fibers with stagnation of collagen fibers. Fragility or thinning of this connective tissue in the nose causes drooping of the tip of the nose and limits airflow and may cause nasal obstruction. In addition to nasal pain, other symptoms of geriatric rhinitis include anosmia, swelling of the nostrils, and dry cough. Nasal discharge may occur in dementia, Parkinson's disease (PD), and Alzheimer's disease (AD). Some drugs are also likely to lead to this condition. That said, nasal discharge may also be a sign of diseases such as PD, AD, and depression. ${ }^{[1]}$

Alzheimer's disease is a clinical syndrome characterized by dementia and progressive decrease in the cognitive fields of carrying out the instrumental and fundamental of daily life including memory, speech, coordination, visual functionality, personality, and behavior. Alzheimer's disease, the most common cause of

Received: May 02, 2019 Accepted: May 27, 2019 Published online: July 31, 2019

Correspondence: Kayhan Özkan, MD. Düzce Üniversitesi, Sağlık Bilimleri Enstitüsü, Fizyoloji Anabilim Dalı, 81620 Düzce, Turkey. Tel: +90 380 - 5421416 e-mail: kayhanozkan@hotmail.com 
dementia worldwide with increasing rates due to aging world population, accounts for $80 \%$ of all diagnoses of dementia. ${ }^{[2]}$ About 50 million people live with $\mathrm{AD}$ worldwide and this number is expected to increase to 100 million by the year 2050. ${ }^{[3]}$ Furthermore, there is not yet an effective drug against AD. ${ }^{[4]}$ Therefore, early diagnosis of $\mathrm{AD}$ is important in its initial stage, and it is necessary to comprehensively evaluate clinical assessments and the potential side effects of drug use. Nonetheless, most patients require long term clinical surveillance for $A D$ diagnosis. Although more than one biomarker has been associated with the disease to increase accuracy of diagnosis, every biomarker has its limitations. These biomarkers have been shown to be ineffective in differentiating between cognitively healthy individuals from those with cognitive dysfunction. A better biomarker that provides early detection of Alzheimer's disease has still not been found. ${ }^{[5]}$ It is estimated that the yearly cost of health care directly associated with $\mathrm{AD}$ and secondary expenses is approximately 500 billion dollars. ${ }^{[6]}$ For this reason, it is important to take measures by evaluating pre-markers before the development of clinical symptoms. Definite diagnosis of $\mathrm{AD}$ constitutes of sequence analysis including evaluation following death of brain tissue, however cerebrospinal fluid (CSF) and positron emission tomography (PET) biomarkers may also be helpful in diagnosis. ${ }^{[7]}$ Magnetic resonance imaging (MRI) and serum and CSF analysis used to show evidence of biomarkers that support pathology of $\mathrm{AD}$ are also preferred to help diagnose other forms of dementia and mild cognitive disorders. ${ }^{[8]}$ In addition to all these, in the early diagnosis of $\mathrm{AD}$, MicroRNA 206, which suppresses neurotrophic factor expression derived from the brain, has been reported to increase in the brains of these patients. One study on dementia patients and cognitively healthy individuals performed biopsy on olfactory epithelial tissue. The biopsied tissue samples were analyzed with polymerase chain reaction $(\mathrm{PCR})$ and microRNA 206 levels were assessed. According to PCR results, microRNA 206 levels were easily measured in mucous membranes containing olfactory cells and it was reported that it could be used as a biomarker for both early diagnosis of $\mathrm{AD}$ and even mild cognitive disorder. ${ }^{[9]}$ With this purpose, it is possible to forestall disease before it starts with the "early warning system model", by detecting precursor molecules in various organs and tissues within the disease-specific response.

\section{THE ROLE OF BIOMARKERS IN EARLY DIAGNOSIS}

Brain-derived neurotrophic factor (BDNF) shows neurotrophic effect through neurons by connecting neurotrophin, which is widely expressed throughout the central nervous system, and its specific receptor to tyrosine receptor kinase $\mathrm{B} .{ }^{[10]}$ Moreover, BDNF is a key molecule that plays a role in maintaining synaptic plasticity and synaptogenesis in the hippocampus, the main locus of memory acquisition and consolidation. ${ }^{[1]}$ Synaptic connections are weakened in AD and experimental animal models have reported decreased BDNF levels in the brain and circulation. ${ }^{[12]}$ However, in spite of this data, some recent studies have reported that BDNF may also decrease in the development of dementia in healthy people. ${ }^{[13]}$

Amyloid beta accumulation, as a result of neuronal injury or neurodegeneration, is another biomarker that may be helpful in the early diagnosis of $\mathrm{AD}{ }^{[14]}$ On the other hand, brain mir-206 levels are elevated in AD patients and may constitute pathogenesis of cognitive deterioration. Brain-derived neurotrophic factor is reported to decrease following mir-206 transcription. Brainderived neurotrophic factor is among the main regulators of synaptic plasticity and memory, and the brains of people with $\mathrm{AD}$ show decreased levels of $\mathrm{BDNF}$ that may be responsible for cognitive impairment. Animal models of AD have conducted various experiments to increase BDNF levels, however further research is required. ${ }^{[15]}$

Parkinson's disease, characterized by neuronal degeneration like $\mathrm{AD}$, has high prevalence of nasal discharge. It is reported that $76 \%$ of patients with this disease have increased symptoms of nasal discharge during meals. Increased nasal mucus is believed to be caused by activation of the sympathetic nervous system. ${ }^{[16]}$ Biomarkers can help diagnose diseases that develop over many years, such as $\mathrm{AD}$. Successful struggle against $\mathrm{AD}$ is based on its preclinical diagnosis. 


\section{TAU PROTEIN ANALYSIS IN NASAL MUCOSA}

Assessment of tau protein levels in nasal mucosa may give an idea on neuronal degeneration in AD patients. Tau proteins belong to a family of proteins associated with microtubules. They have been indicated to play an important role in the stabilization of microtubules of tubulin monomers in the formation of the neuronal microtubular web. Furthermore, tau proteins that soften and separate from microtubules cause interruption in this formation (Figure 1). Microtubules play a role in protecting the structure of the cell and axonal transport. Tau proteins are responsible for the many neurodegenerative disorders known as "tauopathies", or lesions of the main components of intraneuronal and glial cells defined in AD. ${ }^{[16]}$ Neuropathologists have defined many intracellular inclusions such as Hirano bodies, Lewy bodies, Pick bodies, and neurofibrillary tangles. These proteins are constantly found in AD. ${ }^{[17]}$ Tau proteins in the brain form a family of six isoforms ranging from 352 to 441 amino acids. ${ }^{[18]}$ Senile plaques and neurofibrillary tangles are two main brain lesions found in the brain tissue of $\mathrm{AD}$. Senile plaques form as a result of extracellular accumulation of a peptide known as amyloid

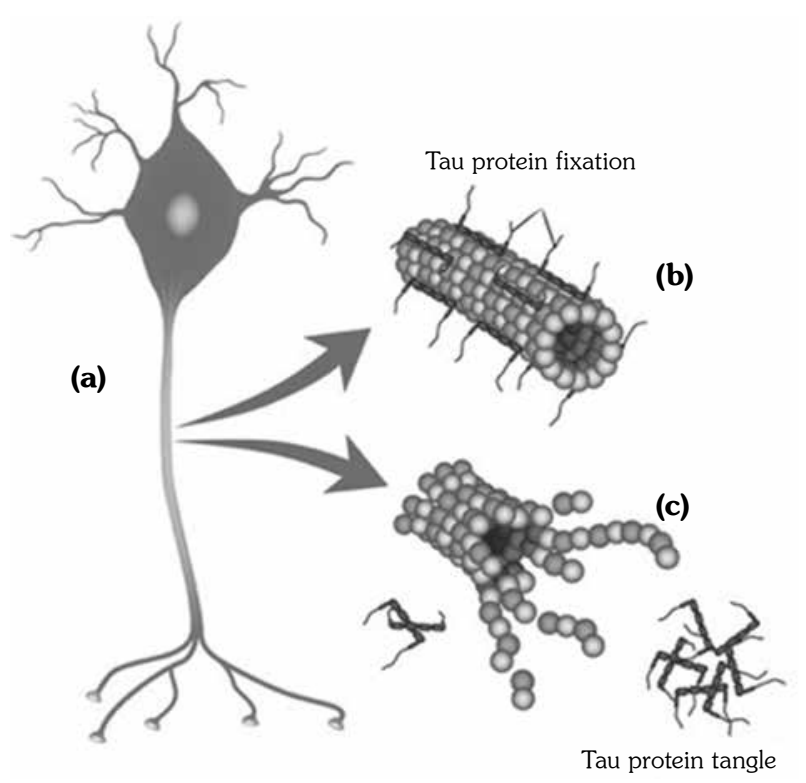

Figure 1. The role of tau proteins in the neuron cell. (a) Neuron cell; (b) Healthy microtubule; (c) Separation of tau protein tangle from the microtubule in Alzheimer's disease. ${ }^{[27]}$ beta. Detection of tau proteins in peripheral tissues may be helpful in the preclinical diagnosis of AD. Tau proteins have been investigated in peripheral tissues and biological fluids in order to identify an ideal AD marker that can be used as a diagnostic tool. Recently, studies on molecular and biochemical markers of $\mathrm{AD}$ have been published and it has been emphasized that the proposed markers of AD should have at least $80 \%$ sensitivity to detect this disease and at least $80 \%$ specificity to distinguish it from other diseases. These non-invasive, applicable, and inexpensive tests have also widely begun to be used.[19]

\section{IMPORTANCE OF NASAL MUCOSA TEST IN ALZHEIMER'S DISEASE}

A study on this subject obtained nasal mucosa biopsy samples from mild and moderate potential AD patients. ${ }^{[20]} \mathrm{T}$ immunoreactivity was detected in thin nerve fibers and some olfactory epithelial cells in the lamina propria of neuropathologically confirmed postmortem tissues of $\mathrm{AD}$ cases. $\mathrm{T}$ immunoreactivity was not detected in the nasal mucosa epithelia of the control group comprised of healthy individuals. ${ }^{[21]}$ This result suggests that markers that play a role in the pathogenesis of neurological diseases may be detected in results obtained from evaluation of the contents of nasal discharge. Brain regions that manage the ability to smell undergo neurodegenerative impairment due to plaques in the olfactory ampulla. However, it is still unknown how pathological neuronal changes spread to the peripheral olfactory epithelia and associated nerve fibers. ${ }^{[22]}$ Another study that used a specific monoclonal antibody panel did not detect presence of amyloid beta in olfactory mucosa in five $\mathrm{AD}$ patients with dementia onset. $^{[21]}$ In contrast to this study, amyloid beta levels were investigated in the nasal secretions of $\mathrm{AD}$ patients using microelectrode biosensors. According to the results of the study, amyloid beta levels in nasal secretions increased in AD and it was suggested that it was possible to predict $A D$ by detecting amyloid beta in nasal secretions by using microelectrode biosensors. ${ }^{[23]}$ Presence of plaques containing neuropathologic biomarkers of Alzheimer's disease, tau proteins and amyloid, has increased the studies on developments of new drugs in the treatment of the disease. It is generally accepted that patients who are partially clinically diagnosed show no evidence of amyloid 
pathology in PET scans and is a subject of debate. Recent developments in research on Alzheimer's disease show that amyloid pathology may begin 20-30 years before clinical onset of AD. These findings are evidence of increased need for confirmed biomarkers in drug development and clinical practice. ${ }^{[24]}$ One study on Abeta- 42 as a potential biological marker of $\mathrm{AD}$ in saliva secretions reported that saliva analysis was a strong indicator of risk in the clinical development of $\mathrm{AD} .{ }^{[25]}$ Analysis of mucosal secretion products is relatively superior to other imaging methods in that it is both non-invasive and cost-effective. Early diagnosis of Alzheimer's disease is helpful in increasing quality of life. Olfactory cortex regions are the first to play a role in AD pathology and patients with $\mathrm{AD}$ often have more degeneration in the left hemisphere. Since the olfactory epithelium is mainly reflected in olfactory cortex in the same side, reduced sense of smell can be observed in $\mathrm{AD}$ patients. Primary olfactory cortex is one of the first pathology sites in AD. ${ }^{\text {[26] }}$

\section{DISCUSSION AND CONCLUSION}

The latest studies have suggested that $\mathrm{AD}$ biomarkers found in nasal discharge is one of the helpful components in early diagnosis. However, primary visual and auditory cortexes are usually preserved in AD patients. Smell test is a sensitive and specific sensory test for $A D$ and is among the fast and non-invasive methods. There will be need for further studies to not only evaluate the effectiveness of these results in predicting $\mathrm{AD}$ but also render them significant. Investigating presence of biomarkers in the contents of nasal discharge and associating them with damage that could occur in neurons has become possible with modern technology. Components such as saliva secretions and nasal mucosa are helpful instruments in the diagnosis of $\mathrm{AD}$ and will become the fundamental element in the struggle against this disease. However, by conducting further studies on this subject, early diagnosis of $\mathrm{AD}$ should take its place among the critical diagnostic techniques of clinical approach.

\section{Declaration of conflicting interests}

The authors declared no conflicts of interest with respect to the authorship and/or publication of this article.

\section{Funding}

The authors received no financial support for the research and/or authorship of this article.

\section{REFERENCES}

1. Abe K. Rhinorrhea and olfaction in Parkinson disease. Neurology 2008;71:1929.

2. Alzheimer's News Today. Available at: http://www. alzheimersnewstoday.com [Access date: 20 Nisan 2019.]

3. Benarroch EE. Brain-derived neurotrophic factor: Regulation, effects, and potential clinical relevance. Neurology 2015;84:1693-704.

4. Bermejo-Pareja F, Antequera D, Vargas T, Molina JA, Carro E. Saliva levels of Abeta1-42 as potential biomarker of Alzheimer's disease: a pilot study. BMC Neurol 2010;10:108.

5. Braak H, Braak E. Demonstration of amyloid deposits and neurofibrillary changes in whole brain sections. Brain Pathol 1991;1:213-6.

6. Budson AE, Solomon PR. New criteria for Alzheimer disease and mild cognitive impairment: implications for the practicing clinician. Neurologist 2012;18:35663.

7. Crous-Bou M, Minguillón C, Gramunt N, Molinuevo JL. Alzheimer's disease prevention: from risk factors to early intervention. Alzheimers Res Ther 2017;9:71.

8. Esiri MM, Wilcock GK. The olfactory bulbs in Alzheimer's disease. J Neurol Neurosurg Psychiatry 1984;47:56-60.

9. Ferreyra-Moyano H, Barragan E. The olfactory system and Alzheimer's disease. Int J Neurosci 1989;49:15797.

10. Goedert M, Spillantini MG, Jakes R, Rutherford $\mathrm{D}$, Crowther RA. Multiple isoforms of human microtubule-associated protein tau: sequences and localization in neurofibrillary tangles of Alzheimer's disease. Neuron 1989;3:519-26.

11. Hock C, Golombowski S, Müller-Spahn F, Peschel O, Riederer A, Probst A, et al. Histological markers in nasal mucosa of patients with Alzheimer's disease. Eur Neurol 1998;40:31-6.

12. Jack CR Jr, Knopman DS, Jagust WJ, Shaw LM, Aisen PS, Weiner MW, et al. Hypothetical model of dynamic biomarkers of the Alzheimer's pathological cascade. Lancet Neurol 2010;9:119-28.

13. Jansen WJ, Ossenkoppele R, Knol DL, Tijms BM, Scheltens P, Verhey FR, et al. Prevalence of cerebral amyloid pathology in persons without dementia: a meta-analysis. JAMA 2015;313:1924-38.

14. Kim YH, Lee SM, Cho S, Kang JH, Minn YK, Park $\mathrm{H}$, et al. Amyloid beta in nasal secretions may be a potential biomarker of Alzheimer's disease. Sci Rep 2019;9:49-66.

15. Mattsson N, Zetterberg $\mathrm{H}$, Hansson $\mathrm{O}$, Andreasen $\mathrm{N}$, Parnetti L, Jonsson M, et al. CSF biomarkers 
and incipient Alzheimer disease in patients with mild cognitive impairment. JAMA 2009;302:385-93.

16. McKhann G, Drachman D, Folstein M, Katzman R, Price D, Stadlan EM. Clinical diagnosis of Alzheimer's disease: report of the NINCDS-ADRDA Work Group under the auspices of Department of Health and Human Services Task Force on Alzheimer's Disease. Neurology 1984;34:939-44.

17. Miura P, Amirouche A, Clow C, Bélanger G, Jasmin BJ. Brain-derived neurotrophic factor expression is repressed during myogenic differentiation by $\mathrm{miR}$ 206. J Neurochem 2012;120:230-8.

18. Moon J, Lee ST, Kong IG, Byun JI, Sunwoo JS, Shin JW, et al. Early diagnosis of Alzheimer's disease from elevated olfactory mucosal miR-206 level. Sci Rep 2016;6:20364.

19. Querfurth HW, LaFerla FM. Alzheime's disease.N Engl J Med 2010;362:329-44.

20. Schlosser RJ, Storck K, Cortese BM, Uhde TW, Rudmik L, Soler ZM. Depression in chronic rhinosinusitis: A controlled cohort study. Am J Rhinol Allergy 2016;30:128-33.

21. Song JH, Yu JT, Tan L. Brain-derived neurotrophic factor in Alzheimer's disease: risk, mechanisms, and therapy. Mol Neurobiol 2015;52:1477-93.

22. Takizawa C, Thompson PL, van Walsem A, Faure C, Maier WC. Epidemiological and economic burden of Alzheimer's disease: a systematic literature review of data across Europe and the United States of America. J Alzheimers Dis 2015;43:1271-84.

23. Buée L, Bussière T, Buée-Scherrer V, Delacourte A, Hof PR. Tau protein isoforms, phosphorylation and role in neurodegenerative disorders. Brain Res Brain Res Rev 2000;33:95-130.

24. Vahia VN. Diagnostic and statistical manual of mental disorders 5: A quick glance. Indian $\mathrm{J}$ Psychiatry 2013;55:220-3.

25. Ball MJ. Neuronal loss, neurofibrillary tangles and granulovacuolar degeneration in the hippocampus with ageing and dementia. A quantitative study. Acta Neuropathol 1977;37:111-8.

26. Selkoe DJ. Alzheimer's disease is a synaptic failure. Science 2002;298:789-91.

27. Weinstein G, Beiser AS, Choi SH, Preis SR, Chen TC, Vorgas D, et al. Serum brain-derived neurotrophic factor and the risk for dementia: the Framingham Heart Study. JAMA Neurol 2014;71:55-61. 